\section{Anatomy past and present}

\author{
Bruce Charlton
}

Having recently taken up a lectureship in anatomy, I have been struck by a prevailing sense of gloom and worry about the subject's future. This is not surprising. Over the past few years several medical schools have decided to dispense with their anatomy divisions. Furthermore, 1989 saw most of the remaining departments given an emphatic "thumbs down" by the then University Grants Committee in its research selectivity exercise: except a handful of high fliers, all scored a minimal one or two points from the possible five.

On the teaching front things are hardly better. Anatomy is regarded among educationalists as perhaps the ultimate horror, concentrating as it often does on memorisation by rote. Despite the efforts of talented lecturing staff the actual material is too often excessive in volume while deficient in conceptual challenge. All of which makes anatomy unloved by the other preclinical sciences, who see their own subjects neglected while anatomy is being crammed.

And yet things were not always thus. In order to understand our present state I have been reading something of the history of the subject. It turns out that anatomy was once a highly respected humane discipline: wildly popular with students and perhaps the first fully developed biological science. In particular, the subject thrived in eighteenth century Scotland. The universities of those days were open access institutions: any male could attend the professorial lectures in any order (if they paid the fees), there were no entrance requirements, and actually getting a degree was not considered very important.

In such a system the professor's income depended mostly on attracting a large and loyal audience, and to some extent this was in competition with the other professors. Adam Smith attributed part of the superiority of Scottish universities to this very direct incentive to good teaching, compared with the fellows of Oxford and Cambridge colleges, who were paid the same whether they taught well or not-and during the eighteenth century they did not!

BMJ 1991;302:1001-2 University of Glasgow, Glasgow G12 800

Bruce Charlton, $\mathrm{MD}$, lecture

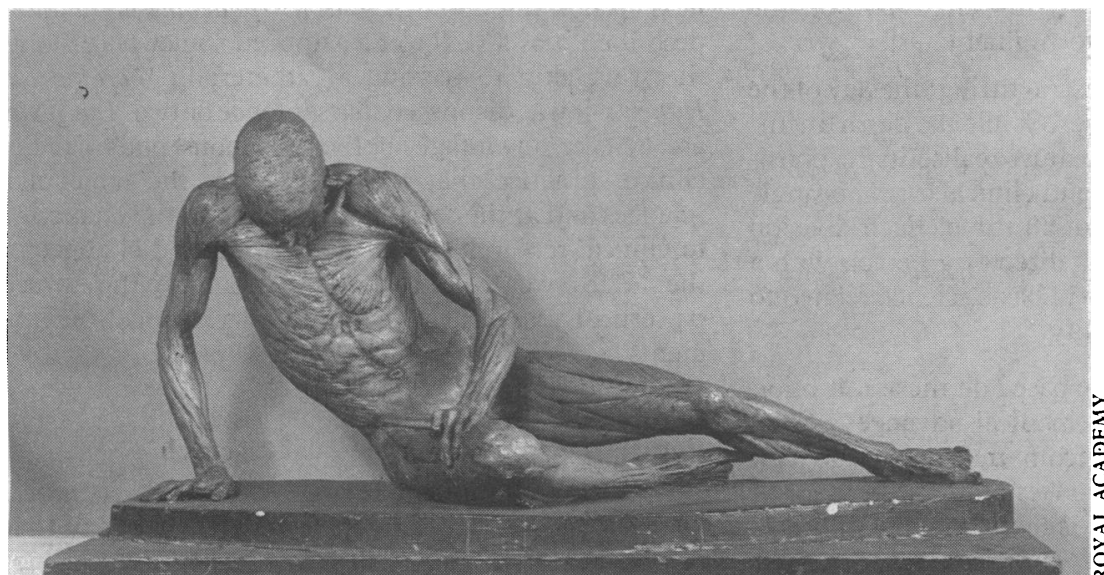

Plaster écorché, the "smugglenius," 1775, used to teach anatomy to artists
Classes contained many types of students compared with today. Few of these would have attended as a compulsory part of the course-only those matriculated future physicians who intended to graduate with an MD (the only medical degree at that time). Some students were on "day release" from apprenticeship to surgeons or apothecaries, others were travelling and studying at various medical schools (the principle of lernfreiheit); there were established practitioners on "refresher courses" and members of the general public. Tested under such rigorous conditions, anatomy emerged as supreme.

Over many decades the lectures of a charismatic professor such as Alexander Munro II at Edinburgh were by far the best attended in the university. So popular, in fact, that it became difficult to get a room large enough even to house the audience: in 1783 his class enrolment of 436 was larger than the entire intake of Oxford and Cambridge combined. And the influence of anatomy spread far beyond medicine. Some scholars believe that there is a case for assuming that the impact of anatomical thought on general society was itself an appreciable stimulus to the Scottish Enlightenment.

What was it about anatomy that so fascinated these people? The subject was much broader than it is now. For example, there was no clear dividing line between anatomy and surgery, an anatomist being a sort of "scientific surgeon." Whether surgeons or not, anatomists were usually active clinicians, and they taught and researched across an even wider range of subjects including botany, chemistry, midwifery, pathology, and physiology. Anatomy was regarded as the single most useful study a doctor could make. There was little an eighteenth century physician could do to influence the course of disease, but a thorough grounding in the structure of the body provided at least a starting point for classification and further investigation.

Furthermore, it seems that the subject of anatomy at that time was not just a combination of present day anatomy with various other present day subjects. It was something strange to us. Among other things it was a kind of natural theology, a demonstration of the rational and benign organisation of God's world. In fact its principal purpose was edification and moral instruction: hence the attendance at dissections by the likes of philosophers and theologians. Anatomy then was a humanity in a way that no multiplication of biological sciences can now replicate.

However, nothing remains unchanged: as science "progressed" it deliberately discarded the trappings of a humanity in favour of "objectivity." Increased research led to an increased complexity which clouded the picture of anatomy's previously clear principles Gradually the links with clinical medicine were eroded and the subject became narrower and more specialised Increasing professionalisation within medical schools meant that medical practice and anatomy were each regarded as full time jobs and therefore harder to 
combine. Anatomy became the study of embalmed bodies and fixed tissues whereas pathology branched off and took with it most of the direct clinical applications, including the study of disease in the recently dead and the examination of fresh tissues for diagnosis. The deficiencies of learning surgery on cadavers became more obvious with rising technical standards in operating-anatomy was reduced to a mere preliminary.

The history of anatomy has been one long retreat from the age of Munro II until now. For the older generation there has been a gradual reduction in the share of the curriculum, in status, in salary (in common with other academics), and in the subject's links with clinical medicine. And each of these changes has been fought every inch of the way, in a rearguard action which was touching in some respects but ultimately wrong headed and doomed to failure.

Where does all this leave the anatomy lecturer embarking on a career in the subject? The problem has been that nostalgia for the past and fear of the future have combined to prevent anatomy making the kind of transition which has been successfully negotiated by physiology, the transition from being a subsidiary of clinical medicine to being a science in its own right. In failing to make this transition anatomy has severed teaching from research-tearing itself in two in the process.

In other words, teaching and research must move towards each other if the subject is to stay in one piece. This is the lesson of the past-viable science requires integration between a relevant teaching role and activity at the cutting edge of research if it is to remain happy and healthy.

This is one possibility. The alternative is a reinte- gration with medicine-perhaps with pathology - to restore not just relevance but also a clinical role. The administrative difficulties and staffing considerations of such change are certainly intimidating, especially in the current financial climate, and of course there would have to be a substantial evolution in the scope of the subject and its orientation, but it would certainly be invigorating.

I cannot see that the status quo is a viable long term option. There is still time to save anatomy, but it requires a willingness to change the nature of the subject; to reverse the destructive trends of two hundred years in favour of expansion and reintegration instead of contraction and fragmentation; to launch a pre-emptive strike instead of consolidating an entrenched resistance. At present, anatomy is just what has been left behind when the other (more interesting?) biological sciences have departed and set up shop independently. Leaving aside the ambitious ideal of clinical reintegration, the minimum formula for survival and success is simple, and yet difficult: more and better research and less and better teaching - the two are intimately linked.

Whether the subject can reform itself from within or whether constructive change can be stimulated from without, I do not know. Perhaps the forces of decline are too large or powerful. Perhaps I am simply being nostalgic even in thinking that anatomy should be saved. Maybe it has condemned itself? But the heady days of the Scottish Enlightenment suggest that there is some kind of broad intrinsic fascination in the subject which, if only it could be presented in a proper context, might restore anatomy to its place in the sun.

(Accepted 20 February 1991)

\section{The physician scientist: an endangered but far from extinct species}

\section{J Weatherall}

Although the recent revolution in the biological sciences offers such exciting prospects for medical research and practice, this is not reflected in the current mood of academic medicine, which is both confused and pessimistic about its future role. This identity crisis is exemplified in the fascinating book Osler's Legacy-The Department of Medicine at Johns Hopkins, 1889-1989, published to coincide with the centennial celebrations of that Mecca for clinical investigators.' For after a century of training physician scientists the department of medicine at Hopkins has changed its organisation and philosophy. In explaining why, John D Stobo, the tenth chairman of the department in succession to William Osler, writes:

"One principle guided the restructuring; the day of the renaissance physician was over. While the department, and therefore each division, must realise its responsibility in research, teaching, and clinical care, no single individual could be master of all three. Each division would, therefore, have as its director a person with a proven record of scholarship in basic science related to the particular clinical speciality."

Arguments of this kind are based on the assumption that most of the important medical advances of the future are likely to come from molecular and cell biology and related basic sciences and that because of their complexity it will no longer be possible for one person to be a competent clinician, teacher, and research worker. This view, argued most cogently by
Gill in his gloomy essay "The end of the physicianscientist?"' has been echoed by many other leaders of American academic medicine.

What has been happening in the United Kingdom while our American colleagues have been indulging in this soul searching? Not much it seems. Although the basic medical sciences were mentioned in the report of the House of Lords Select Committee on Science and Technology Priorities in Medical Research, ${ }^{3}$ the main thrust of its conclusions was directed at strengthening research in the NHS. And papers that have dealt with the staffing and reorganisation of the NHS have said next to nothing about research. Achieving a Balance described it as a skill to be acquired somewhere along the way, akin to passing a catheter; in Working for Patients ${ }^{5}$ it was dismissed in a sentence or two. But if we are to take advantage of the enormous potential for clinical practice that will stem from the molecular sciences and at the same time respond to the challenge to clinical research posed by the profound changes in the NHS, we too will have to examine the future pattern of research in our university clinical departments.

\section{Future development of medical research}

As the revolution in biology which has stemmed from the molecular sciences has been the equal of that in physics at the beginning of this century it is not surprising that the message that the molecular sciences
D I Weatherall, FRs, Nuffield professor of clinical medicine

$B M \mathcal{1} 1991 ; 302: 1002-5$
BMJ VOLUME 302

27 APRIL 1991 